\title{
Analysis of Oocyte and Embryo Numbers, and Pregnancy Rate in Patients Undergone In Vitro Fertilization with Long and Short Protocols
}

\author{
Analisis Jumlah oosit, Embrio, dan Keberhasilan Kehamilan pada Pasien \\ yang Mengikuti Fertilisasi In Vitro dengan Protokol Panjang dan Protokol Pendek
}

\author{
Budi Wiweko, Nadia Shafira, Dwi Priangga, Valencia Yuwono \\ Department of Obstetrics and Gynecology \\ Faculty of Medicine University of Indonesia/ \\ Dr. Cipto Mangunkusumo Hospital \\ Jakarta
}

\begin{abstract}
Objectives: To compare the oocyte count, embryo count, pregnancy rate, and the presence of OHSS in patients undergoing In Vitro Fertilization (IVF) with long and short protocols at Yasmin Clinic, Dr. Cipto Mangunkusumo Hospital, Jakarta.

Methods: A cross sectional study was done at Yasmin Reproductive Clinic, Dr. Cipto Mangunkusumo Hospital, Jakarta, Indonesia. Data was collected from the medical records of 200 infertile women undergoing IVF, 100 women with long protocols and the other 100 with short protocols. Variables compared in these 2 groups are the oocyte count, embryo count, the pregnancy rate, and presence OHSS using Mann-Whitney U Test with SPSS 11 Program.

Result: From 200 women undergoing IVF procedure, $45.5 \%$ of them aged between 35-40 years old, with the youngest is 22 years old and the oldest is 48 years old (average age $=35$ years, $\mathrm{SD}=4.7$ ), and almost half of them (45\%) have BMI between $18.01-23.00 \mathrm{~kg} / \mathrm{m}^{2} .185$ women has primary infertility. These subjects came to the clinic mostly due to male factor (23.5\%), idiopathic cause (19\%), and ovulation disturbance $(13 \%)$, whilst endometriosis, tubal factor, and other factors take just little percentage. When compared between long and short protocols, the number of oocyte retrieved is significantly different ( $\mathrm{p}=0.007, \mathrm{CI}=5.84-7.11)$, whereas embryo numbers $(\mathrm{p}=0.054, \mathrm{CI}=1.80-2.39)$ and the pregnancy rate $(\mathrm{p}=0.525, \mathrm{CI}=0.21$ 0.33 ) found to be not significantly different. There were 2 cases of moderate OHSS developed in the long protocol group.
\end{abstract}

Conclusion: Although the number of embryo produced and the pregnancy rate are found to be not significantly different between the two groups, long protocol of IVF is found to produce more oocyte to be retrieved and develop more OHSS events compared to short protocol. Due to this result, GnRH antagonist can be considered when planning an IVF procedure. However, a longitudinal multicenter study with larger sample size is needed to validate the current data.

[Indones J Obstet Gynecol 2012; 36-2: 95-9]

Keywords: in vitro fertilization, long protocol, pregnancy rate, short protocol

\begin{abstract}
Abstrak
Tujuan: Membandingkan jumlah oosit, embrio, angka keberhasilan kehamilan, dan angka kejadian OHSS pada pasien yang mengikuti program fertilisasi in vitro dengan protokol panjang dan protokol pendek di Klinik Yasmin Rumah Sakit Dr. Cipto Mangunkusumo.
\end{abstract}

Metode: Penelitian ini menggunakan desain potong lintang dilakukan di Klinik Yasmin, pusat layanan gangguan haid dan kesuburan, RS Dr. Cipto Mangunkusumo, Jakarta. Data diambil dari dua ratus rekam medis pasien perempuan infertil yang mengikuti program fertilisasi in vitro (FIV) terbagi ke dalam kedua kelompok yaitu 100 pasien yang menjalani protokol panjang dan 100 yang mengikuti protokol pendek. Variabel yang dibandingkan dari kedua kelompok ini adalah jumlah oosit, embrio, keberhasilan kehamilan, dan angka kejadian OHSS.

Hasil: Dari 200 perempuan yang mengikuti program FIV, 45,5\% di antaranya berusia 35-40 tahun, dengan usia termuda 22 tahun dan tertua 48 tahun (rata-rata 35 tahun, $S D=4,7)$, dan kebanyakan dari mereka (45\%) memiliki BMI di antara 18,01-23,00 kg/ $\mathrm{m}^{2} .185$ perempuan mengalami infertilitas primer. Subjek dalam penelitian ini kebanyakan mengalami infertilitas akibat faktor lelaki (23,5\%), idiopatik (19\%) dan gangguan ovulasi (13\%), sementara penyebab lain seperti endometriosis, faktor tuba, dan faktor lain ditemukan dalam porsi yang lebih kecil. Saat membandingkan antara protokol panjang dan protokol pendek, terdapat perbedaan yang bermakna pada jumlah oosit yang dipetik ( $p=0,007, C I=5,84-7,11)$. Tidak terdapat perbedaan yang bermakna pada jumlah embrio ( $p=0,054, C I=1,80-2,39)$ dan laju kehamilan ( $p=0,525, C I=0,21-0,33)$. Terjadi 2 kasus OHSS derajat sedang pada grup protokol panjang.

Kesimpulan: Walaupun saat membandingkan jumlah embrio dan laju kehamilan pada kedua protokol tidak ditemukan perbedaan yang bermakna, protokol panjang FIV diketahui menghasilkan lebih banyak oosit yang dipetik dan menimbulkan 2 kejadian OHSS dibandingkan dengan protokol pendek. Dari hasil ini, GnRH antagonis dapat dipertimbangkan pada perencanaan prosedur IVF. Namun, studi longitudinal multi-senter dengan jumlah sampel yang lebih besar dibutuhkan untuk validasi data yang ada.

[Maj Obstet Ginekol Indones 2012; 36-2: 95-9]

Kata kunci: fertilisasi in vitro, kehamilan, protokol panjang, protokol pendek

Correspondence: Nadia Shafira. Division of Reproductive Immunoendocrinology and Infertility. Department of Obstetrics and Gynecology. Faculty of Medicine University of Indonesia Jakarta. Telephone: 0816955511, email: nadia_shafira@hotmail.com

\section{INTRODUCTION}

In vitro fertilization (IVF) has been developed since more than 30 years back. Although the fertilization rate has slowly reaching to $90 \%$, the live birth rate of this procedure has been constant with just a slight improvement in these recent years. When added with the pregnancy rate, it only occurs around $35-42 \%$ in all IVF centers worldwide. ${ }^{1}$ In 
Indonesia, its success rate has shown a similar numbers, reaching 48.68\% in women less than 35 years old and $7.94 \%$ in women older than 42 years old. ${ }^{2}$

Women undergone IVF might have one or more possible causes, such as ovulation problem, tubal factor, idiopathic or other causes such as endometriosis and fibroids. ${ }^{3} \mathrm{~A}$ woman may not ovulate because the hypothalamus does not secrete gonadotrophin-releasing hormone (GnRH), which is responsible for stimulating the pituitary gland to produce the luteinizing hormone (LH) and folliclestimulating hormone (FSH) that trigger ovulation. GnRH stimulation to release FSH and LH will induce the development of follicles. When there is an ovulation problem in a woman, and she went to seek a fertility treatment, often one of the two types of GnRH analogues, GnRH-agonists and GnRHantagonists, is given together with other related drugs, such as gonadotrophin recombinant and hCG, to enhance stimulation for in vitro fertilization (IVF) process or intra uterine insemination (IUI). These GnRH analogues have an important role in reducing the incidence of premature LH surges by blocking pituitary secretion. ${ }^{4,5}$

GnRH agonist have been widely used as the "gold standard" protocol in ovarian stimulation for more than 20 years. $^{6} \mathrm{GnRH}$ antagonist that recently introduced 7 has offered several advantages, including lower total dosages of gonadotrophins, less incidence of hyperstimulation syndrome, lower cost, lack of side effects, shorter duration of treatment and more individualized and less aggressive protocol. ${ }^{8,9}$

These two GnRH analogues have different ways in inducing ovulation. The GnRH-agonists used in the long protocol, which started either in the mid luteal phase or in the early follicular phase of the preceding cycle, will cause an initial surge in both FSH and LH production. But then it will cause the body to cease production of these hormones, thus preventing ovulation and limiting estrogen. Meanwhile GnRH-antagonists, used in short protocol, will immediately suppressing the FSH and LH production, thus suppressing ovulation. ${ }^{10}$

Several studies have directly compared these new stimulation protocols against the long GnRH agonist protocol in terms of number of oocytes collected, number of embryos obtained, implantation rate, and mainly focus on pregnancy rate and incidence of ovarian hyperstimulation syndrome (OHSS). Although several data has previously describes that GnRH antagonist have a lower pregnancy rate, ${ }^{10-13}$ another data has shown that the live birth probability between two groups was not significantly different.14 The development of OHSS cases was reported to be higher in the long protocol group compared to the short one.12,15 Devroey and Andriaensen (2011) also emphasize that in order to avoid the presence of OHSS, clinician should do all stimulations with $\mathrm{GnRH}$ antagonist. ${ }^{16}$

\section{OBJECTIVES}

Looking at the previously reported data, our current study tried to compare several outcome variables of IVF between two protocols. The objective of this study was to compare the oocyte count, embryo count, the pregnancy rate, as well as the presence of OHSS in women undergone In Vitro Fertilization (IVF) with long and short protocols at Yasmin Clinic, Dr. Cipto Mangunkusumo Hospital, Jakarta. This first pilot project done in Indonesia is aiming to look for the different outcome between giving GnRH agonist and $\mathrm{GnRH}$ antagonist in such patients.

\section{METHODS}

This present study used a cross sectional design of a total 200 patients. The patients in the study were women who attended Yasmin Reproductive Clinic, Dr. Cipto Mangunkusumo Hospital, Jakarta, Indonesia, and undergoing IVF in the period between November 2009 and March 2011. Patients who came between this period with uncompleted data or cancelled procedure are not included in the study. The data were collected from the medical records, which then divided into 2 groups, 100 women with long protocols and the other 100 with short protocols. No ethical approval was needed, as it is a cross sectional analysis of already available data.

The long protocol controlled ovarian hyperstimulation used combination of gonadotrophin releasing hormone (GnRH) agonist (Suprefact, Buserelin) and recombinant FSH (r-FSH) (Puregon, Gonal). The short protocol controlled ovarian hyperstimulation used combination of GnRH antagonist (Cetrotide) and r-FSH (Puregon, Gonal). The admi- 
Table 1. Data distribution based on patient's age and BMI.

\begin{tabular}{lccccccc}
\hline \hline & \multicolumn{2}{c}{ Age } & & BMI & \\
\hline & $<35$ & $35-40$ & $>40$ & $<18.0$ & $18.01-23.00$ & $23.01-25.00$ & $>25.01$ \\
Overall & $89(44.5 \%)$ & $91(45.5 \%)$ & $20(10 \%)$ & $11(5.5 \%)$ & $90(45 \%)$ & $54(27 \%)$ & $45(22.5 \%)$ \\
Long Protocol & 47 & 46 & 7 & 8 & 43 & 29 & 20 \\
Short Protocol & 42 & 45 & 13 & 3 & 47 & 25 & 25 \\
\hline \hline
\end{tabular}

nistration of GnRH agonist, r-FSH, GnRH antagonist, hCG injection, gametes disposing, embryo culture, and embryo transfer were all undergone according to our regular manipulation in Yasmin Clinic. Fourteen days after pituitary desensitization with GnRH agonist, there was evaluation of follicle maturation by ultrasonography and by serum oestradiol concentration. Then r-FSH was administered at a dose of 150-450 IU according to the ovarian reserve. The r-FSH dose was adjusted according to the degree of ovarian response, evaluated by ultrasound examination and by serum estradiol concentration. The hCG administration (5000 IU-10000 IU) was done if there was follicles of $>18 \mathrm{~mm}$ in diameter, usually on day 12-14 of rFSH administration. Oocytes were retrieved 32-36 hours after hCG administration under transvaginal ultrasound guidance.

Embryos were transferred 2 or 3 days later after oocyte retrieval. The embryos were evaluated by embryologist on the day of fertilization, day of cleavage I, and day of cleavage II. The evaluation included the blastomeres and fragmentation. Embryos with $\geq 4$ cells on cleavage I and embryos with $\geq 8$ cells on cleavage II were calculated. All embryos calculated had $<20 \%$ fragmentation of the total embryonic volume.

A serum $B$-hCG test was done to confirm pregnancy two weeks after embryo transfer. Clinical pregnancy was diagnosed 3 weeks after a positive test by the presence of a gestational sac with fetal echoes and pulsations on ultrasound.

Data were presented as mean \pm SD. Different variables compared in these 2 groups were the oocyte count, embryo count, the pregnancy rate, and the presence of OHSS with the analysis using Mann-Whitney U Test from SPSS 11 Program. P values $<0.05$ were considered to be significant. Statistics were done using SPSS version 11.

\section{RESULT}

This study include a total of 200 women, whose age ranging between 22-48 years old (mean 35.6 \pm 4.6 ) and BMI between $19.55-35.49 \mathrm{~kg} / \mathrm{m}^{2}$ (mean 23.03 \pm 3.4 ), who are divided into two groups: group I (long protocol) included 100 subjects, while group II (short protocol) included 100 subjects. There was no statistically significant difference between the two groups regarding their age and BMI level. With $45.5 \%$ of them aged between $35-40$ years old and most of them (45\%) have BMI between $18.01-23.00 \mathrm{~kg} / \mathrm{m}^{2}, 185$ women has primary infertility.

These subjects came to the clinic mostly due to male factor (23.5\%), idiopathic cause (19\%), and ovulation disturbance (13\%), whilst endometriosis, tubal factor, and other factors take just little percentage (Table 2).

Table 2. Causes of Patient's Infertility.

\begin{tabular}{lccc}
\hline \hline & Overall & $\begin{array}{c}\text { Long } \\
\text { Protocol }\end{array}$ & $\begin{array}{c}\text { Short } \\
\text { Protocol }\end{array}$ \\
\hline Idiopathic & $38(19 \%)$ & 25 & 13 \\
Endometriosis & $20(10 \%)$ & 6 & 14 \\
Ovulation Disturbance & $26(13 \%)$ & 7 & 19 \\
Male Factor & $47(23.5 \%)$ & 25 & 22 \\
Tubal Factor & $18(9 \%)$ & 11 & 7 \\
Male and Female Factors & $29(14.5 \%)$ & 14 & 15 \\
Others & $22(11 \%)$ & 12 & 10 \\
\hline \hline
\end{tabular}

The antral follicle count (AFC) and basal hormonal level characteristics of the patients recruited in this study varies as shown in Table 3. 
Table 3. Basal Level Characteristics.

\begin{tabular}{lccc}
\hline \hline \multicolumn{1}{c}{ Basal Level } & Minimum & Maximum & Mean \\
\hline FSH & 1.2 & 39 & $7.78 \pm 4.57$ \\
E2 & 8 & 505.27 & $52.41 \pm 51.04$ \\
LH & 0.1 & 39 & $5.48 \pm 5.27$ \\
$\begin{array}{l}\text { Anti-Müllerian } \\
\text { Hormone (AMH) }\end{array}$ & 0.1 & 13.7 & $3.08 \pm 3.21$ \\
$\begin{array}{l}\text { Antral Follicle } \\
\text { Count (AFC) }\end{array}$ & 0 & 20 & $7 \pm 3.65$ \\
\hline \hline
\end{tabular}

Regarding all women, clinical pregnancy was achieved in 54 women $(27 \%)$ and miscarriage rate was $12.9 \%$ mainly in the first eight weeks. There are 4 cases of twin and 1 triplets in long protocol whereas 5 twin cases in the short protocol group.

Table 4. Outcome measures in both groups.

\begin{tabular}{lcccc}
\hline \hline \multicolumn{1}{c}{ Variable } & $\begin{array}{c}\text { Long } \\
\text { Protocol }\end{array}$ & $\begin{array}{c}\text { Short } \\
\text { Protocol }\end{array}$ & $\begin{array}{c}\mathbf{p} \\
\text { Value }\end{array}$ & CI \\
\hline Oocyte Count & $7.22 \pm 4.60$ & $5.73 \pm 4.41$ & 0.007 & $5.84-7.11$ \\
Embryo Count & $2.26 \pm 1.95$ & $1.93 \pm 2.26$ & 0.054 & $1.80-2.39$ \\
$\begin{array}{l}\text { Clinical Pregnancy } \\
\quad \text { Rate }\end{array}$ & $29 \%$ & $25 \%$ & 0.525 & $0.21-0.33$ \\
OHSS & 2 & 0 & 0.156 & $-0.04-0.08$ \\
\hline \hline
\end{tabular}

As presented in Table 4, when the variables are compared between long and short protocols, the number of oocyte retrieved is significantly different, whereas embryo numbers and the pregnancy rate found to be not significantly different. Two cases of OHSS were developed in the long protocol group.

\section{DISCUSSION}

The result of current study is consistent with previous studies mentioning that there is no significant different of the pregnancy outcome from both groups. Despite looking at the significant higher number of oocytes retrieved in the long protocol group, a direct conclusion about the superiority of long protocol cannot be taken since the embryo count and the pregnancy rate has no significant difference between these two groups. Due to this, the use of short protocol should be taken into consideration. Even though the finding of moderate $\mathrm{OH}$ SS development is not significantly different between the two groups, the fact that OHSS only de- veloped in the long protocol group should be taken into consideration when choosing the treatment for such patients, and it was consistent with previous studies reporting the same result. To add to the statement, many previous studies has also discussed and reported that the use of short protocol can reduce the presence of mild, moderate, and mostly, severe OHSS cases.

Our current study is a pilot project involving only 1 IVF center in Jakarta, Indonesia, and it is the first study to compare the outcome of IVF between long and short protocols. A limitation of this study is that the patient's age range is too wide, whilst if the data narrowed down into just a group of age (e.g. more than 40 years old), the number of data will be small. This should be taken into consideration when doing a further study. As discussed previously, because the subjects are taken from only 1 center, the data cannot be used as general information. A further study from multiple IVF centers is needed to validate the data provided. Furthermore, adding more variables to be compared, such as the live birth rate, will also make the data more comprehensive.

\section{CONCLUSION}

Although the number of embryo produced and the pregnancy rate is found to be not significantly different between the two groups, long protocol of IVF found to produce more oocyte retrieved compared to short protocol. Long protocol also produced 2 OHSS event, thus clinician should be more careful in using this protocol for their patients. This data provides a suggestion of using $\mathrm{GnRH}$ antagonist or short protocol for IVF because of their benefits. However, a longitudinal multicenter study with larger sample size is needed to validate the current data.

\section{REFERENCES}

1. Andersen AN, Goossens V, Gianaroli L, Felberbaum R, de Mouzon J, Nygren KG. Assisted reproductive technology in Europe, 2003. Results generated from European registers by ESHRE. Hum Reprod. 2007; 22(6): 1513-25

2. Keberhasilan Program Bayi Tabung Indonesia Tahun 2010. Perfitri Update Edisi 2. 2011: 6-7

3. Taylor A. Extent of the problems. In: Braude P and Taylor A. ABC of Subfertility. BMJ 2003; 327: 434-6

4. Loumaye E. The control of endogenous secretion of LH by gonadotrophin-releasing hormone agonists during ovarian hyperstimulation for invitro fertilization and embryo transfer. Hum Reprod 1990; 5: 357-76 
5. Al-Inany HG, Youssef MAFM, Aboulghar M, Broekmans F, Sterrenburg M, Smit J, Abou-Setta AM. Gonadotrophin releasing hormone antagonists for assisted reproductive technology. Cochrane Database of Systematic Reviews 2011, Issue 5. Art. No.: CD001750

6. Biljan MM, Tan SL. Cummulative pregnancy and live birth rates after assisted conception. Croat Med J. 1998; 39(2): 171-80

7. Felberbaum RE, Kupker W, Diedrich K. Will GnRH antagonists assist in the treatment of benign gynaecological diseases? Reprod Biomed Online. 2002; 5 Suppl 1(3): 68-72

8. European and Middle East Orgalutran Study Group. Comparable clinical outcome using the $\mathrm{GnRH}$ antagonistganirelix or a long protocol of the GnRH agonist triptorelin for the prevention of premature LH surges in women undergoing ovarian stimulation. Hum Reprod. 2001; 16(4): 644-51

9. Shapiro DB, Mitchell-Leef D. GnRH antagonist in in vitro fertilization: where we are now. Minerva Ginecol, 2003; 55: 373-88

10. Abracia M, Farina A, Poverini R, Morgia F, Schimberni M, Aragona C. Short versus long gonadotrophin-releasing hormone analogue suppression protocols for superovulation in patients $>$ or $=40$ years old under going intracytoplasmic sperm injection. Fertil Steril. 2005; 84(3): 644-8
11. Al-Inany H, Aboulghar M. GnRH antagonist in assisted reproduction: a Cochrane review. Hum Reprod. 2002; 17(4): 874-85

12. Al-Inany HG, Aboulghar M, Mansour R, Proctor M. Recombinant versus urinary human chorionic gonadotrophin for ovulation induction in assisted conception. Cochrane Database Syst Rev. 2005(2): CD003719

13. Youssef H, El Deeb W, Metawe M, Goda H, Shawky O. GnRH agonist long protocol versus short protocol in women 40 years or more under going ICSI: a multicenter study. Middle East Fertil Society J 2008; 13(1): 63-6

14. Kolibianakis EM, Collins J, Tarlatzis BC, Devroey P, Diedrich $\mathrm{K}$, Griesinger G. Among patients treated for IVF with gonadotrophins and GnRH analogues, is the probability of live birth dependent on the type of analogue used? A systematic review and meta-analysis. Hum Reprod Update. 2006; 12(6): 651-71

15. Ludwig M, Katalinic A, Diedrich K. Use of GnRH antagonists in ovarian stimulation for assisted reproductive technologies compared to the long protocol. Meta-analysis. Arch Gynecol Obstet. 2001; 265(4): 175-82

16. Devroey P and Andriaesen P. OHSS Free Clinic. F, V, \& V in OBGYN 2011; 3(1): 43-5 